\title{
Analisis Dampak Migrasi Dalam Meningkatkan Pertumbuhan Ekonomi Keluarga Desa (Studi Pada Desa Tanjung Gusti, Kecamatan Galang, Kabupaten Deli Serdang, Sumatera Utara)
}

\author{
Vina Maria Ompusunggu \\ Fakultas Ekonomi Universitas Quality \\ Jalan Ngumban Surbakti No.18, Sempakata Medan Selayang, Sumatera Utara 20132 \\ e-mail: vinaompusunggu@gmail.com
}

\begin{abstract}
ABSTRAK
Penelitian dilakukan di Desa Tanjung Gusti, Kecamatan Galang, Kabupaten Deli Serdang, Sumatera Utara, dengan tujuan untuk mengetahui bagaimana dampak migrasi dalam meningkatkan pertumbuhan ekonomi keluarga desa. Penelitian ini menggunakan data kualitatif yang bertujuan menggambarkan secara detail dan mendalam tentang dampak migrasi dalam meningkatkan pertumbuhan ekonomi keluarga desa. Teknik pengumpulan data adalah dengan teknik wawancara dan studi dokumentasi untuk memperoleh informasi yang lengkap. Jumlah Informan penelitian ini adalah sekitar 35 orang dan semuanya diciptakan sebagai sampel total. Hasil penelitian menunjukkan bahwa terdapat peranan migrasi dalam meningkatkan pertumbuhan ekonomi keluarga desa. Berdasarkan data, 65\% mata pencaharian masyarakat Desa Tanjung Gusti adalah bertani dan berdagang. Untuk itu migrasi sirkuler sebagai faktor peningkatan ekonomi keluarga desa. Hal ini dapat dilihat adanya dampak positif dan dampak negatif terhadap pertumbuhan ekonomi keluarga desa.
\end{abstract}

Kata Kunci: Dampak Migrasi, Pertumbuhan Ekonomi Keluarga, Desa 


\title{
Analysis of the Impact of Migration in Increasing Economic Growth of Village Families (Study in Tanjung Gusti Village, Galang District, Deli Serdang District, North Sumatra)
}

\begin{abstract}
The study was conducted in Tanjung Gusti Village, Galang District, Deli Serdang Regency, North Sumatra, with the aim of finding out how the impact of migration in increasing the economic growth of rural families. This study uses qualitative data that aims to describe in detail and in depth the impact of migration in increasing the economic growth of rural families. Data collection techniques are interview techniques and documentation studies to obtain complete information. The number of informants in this study was around 35 people and all of them were created as total samples. The results of the study show that there is a role for migration in increasing the economic growth of rural families. Based on the data, 65\% of the livelihoods of the people of Tanjung Gusti Village are farming and trading. Circular migration is therefore a factor in improving the economy of the village family. This can be seen as a positive and negative impact on the economic growth of the village family.
\end{abstract}

Keywords: Impact of Migration, Family Economic Growth, Village 


\section{PENDAHULUAN}

Pembangunan ekonomi yang tidak merata di wilayah menyebabkan ketimpangan antara pedesaan dengan perkotaan. Pada tahun 2015 jumlah desa di Indonesia berkisar 80.651 desa, dimana $45 \%$ desa tergolong ke dalam kategori desa tertinggal. Pembangunan ekonomi di desa-desa perlu diperhatikan dalam meningkatkan pembangunan ekonomi Indonesia. Todaro (2004) mengungkapkan bahwa migrasi adalah suatu proses perpindahan sumber daya manusia dari tempat-tempat yang produk marjinal sosialnya nol ke tempat lain yang produk marjin sosialnya bukan hanya positif, tetapi juga akan terus meningkat dimana yang berhubungan dengan adanya kemajuan teknologi dan akumulasi modal. Goldscheider (1985) menggambarkan terdapat variasi tipe-tipe migrasi yang kompleks dalam struktur sosial di masyarakat. Oleh sebab itu, perubahan struktur sosial masyarakat tidak hanya mengubah pola-pola migrasi, tetapi perubahan migrasi secara perlahan-lahan dapat mengubah struktur sosial masyarakat di kelompok-kelompok sosial yang berbeda. Migrasi dapat menyebabkan perubahan struktur ekonomi-sosial yaitu "proses perubahan susunan hubungan-hubungan ekonomi-sosial (sebagai akibat pembangunan)."

Lee (1966) dalam teorinya (Push-Pull Theory) mengatakan bahwa migrasi dari desa ke kota disebabkan beberapa faktor pendorong di desa dan penarik di kota, dimana proses pengambilan keputusan untuk bermigrasi dipengaruhi oleh empat faktor, yaitu: faktorfaktor yang terdapat di daerah asal, faktor-faktor rintangan, faktor-faktor yang terdapat di daerah tujuan, dan faktor-faktor pribadi. Ada 3 faktor yang ada di daerah asal dan tujuan, yaitu faktor-faktor daya tarik (pull factor), faktor-faktor daya dorong (push factor), dan faktor-faktor yang bersifat netral (neutral). Faktor-faktor yang bersifat netral pada dasarnya tidak berpengaruh terhadap pengembilan keputusan untuk bermigrasi. Todaro (2004) menerangkan bahwa pemukiman-pemukiman kumuh di perkotaan disebabkan karena semakin tingginya pertumbuhan migrasi dari desa ke kota.

Pengembangan pedesaan tidak dapat dilepaskan dari kondisi ekonomi sosial masyarakat dan kemampuan masyarakat dalam mengakses sumberdaya yang tersedia. Limitasi dalam akses dan pemanfaatan sumberdaya berakibat pada rendahnya kesempatan kerja pedesaan. Dengan demikian keluarga petani dituntut untuk melakukan diversifikasi penghidupan yang salah satunya melalui migrasi. Meningkatnya pertumbuhan ekonomi mempengaruhi penduduk suatu daerah untuk melakukan migrasi agar pendapatannya meningkat dan juga meningkatkan kesejahteraan dari masyarakat.

Desa Tanjung Gusti adalah desa yang berada di Kecamatan Galang Kabupaten Deli Serdang, Sumatera Utara, Indonesia. Galang merupakan jalur alternatif menuju kota Tebing Tinggi dengan terlebih dahulu melalui kecamatan Dolok Masihul yang merupakan salah satu kecamatan di Kabupten Serdang Bedagai. Mata pencaharian penduduk di Desa Tanjung Gusti beraneka ragam, diantaranya petani dan pedagang. Kesempatan kerja di desa tersebut masih terbatas. tingkat pengangguran yang tinggi dan pendapatan yang relatif rendah. Untuk itulah masyarakat perlu melakukan migrasi untuk dapat meningkatkan pendapatan dalam mendukung kesejahteraan ekonomi keluarga. 


\section{Published December 2018}

EKONOMIKAWAN : Jurnal IImu Ekonomi dan Studi Pembangunan

ISSN : 1693-7600 (Print), ISSN : 2598-0157 (Online), http://jurnal.umsu.ac.Id/index.php/ekawan

\section{METODE}

Penelitian ini adalah penelitian kualitatif dengan metode deskriptif, yang berusaha memecahkan masalah dengan melihat masalah-masalah yang ada. Penelitian kualitatif mengutamakan makna, yaitu berkisar pada persepsi orang tentang suatu peristiwa dari data yang didapatkan dari hasil sebuah penelitian. Peneliti berusaha menggali, mengidentifikasi, menjelaskan, meringkas berbagai kondisi yang berhubungan dengan peranan migrasi dalam meningkatkan pertumbuhan ekonomi keluarga desa, khususnya pada Desa Tanjung Gusti, Kecamatan Galang, Deli Serdang, Sumatera Utara.

Informan penelitian adalah orang yang memberikan informasi mengenai situasi dan kondisi latar belakang penelitian, dimana informan tersebut betul-betul mengetahui permasalahan yang akan diteliti. Prosedur dan tahapan analisis data yang dilakukan adalah : Pertama, pengumpulan data yang diawali dengan memasuki lokasi penelitian kemudian menemui informan penelitian untuk diwawancarai dan pengambilan dukumen yang dibutuhkan dengan lengkap. Kedua, reduksi data yaitu memilih data yang benar-benar diperlukan sebagai data utama dan juga data pelengkap. Data yang diperoleh dari lokasi penelitian akan diuraikan dalam laporan yang terperinci dan lengkap serta difokuskan pada hal-hal yang penting. Ketiga, klasifikasi data dimana data yang terkumpul selama penelitian dikelompokkan sesuai dengan tujuan penelitian, mana yang masuk kepada bentuk-bentuk pembinaan, hambatan-hambatan dan juga upaya-upaya yang dilakukan. Keempat, penyajian data untuk melihat gambaran secara keseluruhan atau bagian-bagian tertentu dari penelitian. Kelima, penarikan kesimpulan.

\section{HASIL DAN PEMBAHASAN}

Masyarakat pedesaan merupakan dasar awal dalam pembangunan di Indonesia, dimana pada umumnya sebagian besar dikategorikan sebagai masyarakat miskin. Pemenuhan akan kebutuhan mereka pun rasanya masih sulit untuk terpenuhi. Kemajuan perekonomian di berbagai desa dan seluruh wilayah merupakan bagian penting dalam pembangunan ekonomi negara. Kondisi desa saat ini pun masih cukup memprihatinkan, sekitar 45\% desa di Indonesia masih masuk dalam kategori tertinggal. Oleh karena itu, kemajuan perekonomian desa perlu dilakukan keseimbangan terhadap kesempatan ekonomi antara kota dan desa adalah dilakukannya migrasi sirkuler.Migrasi sirkuler merupakan perpindahan penduduk sementara. Misalnya adalah masyarakat yang bepergian dari tempat asal (rumah) ke tempat pekerjaan. Karena dengan kesadaran penuh akan membangun peningkatan ekonomi desa yang lebih kuat dan maju dengan adanya migrasi sirkuler yang terencana.

Migrasi Sirkuler adalah salah satu faktor peningkatan ekonomi desa. Migrasi adalah perpindahan penduduk dari satu tempat ke tempat lain melampaui batas negara maupun batas administratif negara. Hal ini dikatakan Kartomo (Wirosuhadjo, 1981:116) bahwa bila seseorang tidak bermaksud menetap di daerah yang didatangi dan telah tinggal di daerah itu kurang dari tiga bulan, maka orang tersebut dapat digolongkan dalam migrasi sirkuler. 


\section{Published December 2018}

\section{EKONOMIKAWAN : Jurnal Ilmu Ekonomi dan Studi Pembangunan}

ISSN : 1693-7600 (Print), ISSN : 2598-0157 (Online), http://jurnal.umsu.ac.id/index.php/ekawan

Pergerakan penduduk adalah bagian integral dari perubahan pembangunan secara menyeluruh yang menyebabkan dampak dari transformasi ekonomi dan sosial suatu daerah. Oleh karena itu, tidak terlalu tepat untuk hanya melihat dan menilai dari aspek positif maupun negatif dari mobilitas penduduk terhadap pembangunan yang ada, tanpa mempertimbangkan pengaruh baiknya. Pengarahan penyebaran penduduk pun tidak akan terjadi tanpa adanya kegiatan pembangunan itu sendiri. Teori Lee (1966) "Dorong Tarik" (Push-Pull Theory) menerangkan bahwa ada empat faktor yang mempengaruhi proses pengambilan keputusan untuk bermigrasi, yaitu: faktor-faktor yang terdapat di daerah asal, di daerah tujuan, faktor-faktor rintangan, dan faktor-faktor pribadi. Ada tiga faktor-faktor yang terdapat didaerah asal dan tujuan, yaitu: faktor-faktor daya dorong (push factor), faktor-faktor daya tarik (pull factor), dan faktor-faktor yang bersifat netral (neutral).

Desa sering sekali digambarkan dalam kategori kehidupan yang miskin, karena perekonomian di desa dipandang sangat tertinggal dibandingkan dengan di kota. Tidak hanya itu saja, dianggap tidak memiliki masa depan yang bagus untuk kemajuan desa terhadap sumber daya alam maupun sumber daya manusia. Mata pencahariaan utama di desa biasanya adalah di sektor pertanian, tetapi kenyataannya sekarang ini sektor pertanian sudah tidak dapat menyejahterakan masyarakat desa lagi. Rusli (1982), menyatakan bahwa tingkat upah yang rendah dari pekerjaan-pekerjaan pertanian mendorong penduduk desa untuk cenderung mencari pekerjaan-pekerjaan diluar dari sektor pertanian seperti pekerjaan di bidang industri manufaktur. Mantra (1981), menambahkan adanya kekuatan yang mendorong penduduk untuk pergi ke daerah lain, yaitu ; ketidakpuasan pendapatan di bidang pertanian, kurangnya kesempatan kerja dan keterbatasan fasilitas.

Dengan adanya masyarakat desa melakukan migrasi ke kota, ternyata hasilnya mereka tidak dapat bertahan lama hidup di kota. Karena desa mempunyai penarik yang kuat sebagai tempat tinggal, yaitu adanya ikatan keluarga, biaya hidup murah, dan bisa melakukan bercocok tanam. Dalam hal ini Mantra (1981) mencoba menjelaskan bahwa kekuatan yang menarik penduduk untuk tetap tinggal di desa (kekuatan sentripetal) yaitu:

a. Ikatan kekeluargaan dan persaudaraan yang erat, yang tercermin dari semboyan "Mangan ora mangan waton kumpul".

b. Pemilikan tanah pertanian memberikan status yang tinggi, karena itu enggan meninggalkan desa untuk menetap di daerah lain.

c. Ikatan batin dengan leluhur mereka, dilakukan dengan mengunjungi makam leluhur setiap bulan ruwah (sya'ban) dan lebaran (syawal).

d. Ongkos transportasi yang tinggi bila dibandingkan dengan pendapatan mereka. Untuk mengatasi kekuatan-kekuatan ini maka penduduk desa memilih jalan tengah yaitu dengan migrasi sirkuler.

e. Sistem gotong royong yang kuat, yakni tiap warga desa merasa mempunyai tugas moral untuk saling membantu warga desa yang lain. 


\section{Published December 2018}

\section{EKONOMIKAWAN : Jurnal Ilmu Ekonomi dan Studi Pembangunan}

ISSN : 1693-7600 (Print), ISSN : 2598-0157 (Online), http://jurnal.umsu.ac.id/index.php/ekawan

Dari hubungan antara migrasi sirkuler dan peningkatan ekonomi di desa bahwa migrasi sirkuler menjadi bagian yang efektif bagi peningkatan ekonomi desa. Hal ini dapat terlihat dari migrasi sirkuler yang pendapatannya mengalami peningkatan setiap bulannya yang selalu dikirimkan kepada keluarga mereka di desa. Hal inilah terlihat adanya peningkatan GDP desa dan peningkatan taraf hidup masyarakat desa. Uang kiriman tersebut sebagian besar dimanfaatkan untuk memperbaiki kebutuhan dasar mereka, seperti ; sandang, pangan, dan papan serta selebihnya digunakan untuk memperbaiki infrastruktur desa.

Dampak migrasi sirkuler terhadap peningkatan ekonomi desa telah meningkatkan taraf kehidupan ekonomi masyarakat desa. Dimana migrasi dapat menyebabkan adanya perubahan struktur ekonomi-sosial. yaitu "proses perubahan susunan hubungan ekonomisosial (sebagai akibat pembangunan). Desa penting memiliki sebuah lembaga keuangan yang berguna dalam mengelola keuangan para migran sehingga membantu peningkatan pembangunan desa agar kelanjutan pembangunan terkontrol dengan baik. Pada umumnya masyarakat Kecamatan Galang (khususnya Desa Tanjung Gusti) tidak bersemangat untuk mengembangkan dirinya sehingga masyarakat terpaksa pergi meninggalkan desanya. Oleh sebab itu, perginya masyarakat dari desa, hanyalah bersifat sementara. Migrasi yang didasarkan pada keinginan meningkatkan ekonomi merupakan migrasi yang direncanakan oleh masyarakat itu sendiri secara sukarela dengan kata lain disebut voluntary planned migraton. Tidak adanya unsur paksaan bagi penduduk yang akan berpindah.

Migrasi yang dilakukan masyakarat memiliki dampak positif dan negatif, dimana dampak positifnya sebagai berikut:

a. Imigran dapat membantu memperbaiki infrastruktur di desa. Dana pembangunan dikumpulkan secara kolektif oleh lembaga tersebut untuk memperbaiki sarana dan prasarana di desa. Contonya dibangunnya jalan, gedung sekolah, rumah ibadah, saluran irigasi, dan kantor kepala desa. Contoh kasus di Desa Jaharum A dan Jaharum B, kecamatan Galang. Kondisi infrastuktur yang terdapat di desa awalnya sangat buruk, namun seiring dengan berkembangnya informasi dan semakin luasnya pandangan masyarakat tentang pentingnya sarana dan prasarana, masyarakat bersamasama memperbaiki sarana dan prasarana yang ada, seperti, air bersih disalurkan dari gunung melalui pemasangan selang-selang sampai ke tempat-tempat penampungan air yang tersedia dan pembuatan WC Umum.

b. Kebutuhan dasar semakin lebih baik, dimana masyarakat dapat memenuhi makanan yang bergizi, dapat memperbaiki rumah-rumah mereka, dan telah adanya beberapa lembaga-lembaga kesehatan seperti posyandu dan puskesmas di desa untuk meningkatkan kesadaran masyarakat bahwa menjaga kesehatan dan memperbaiki gizi masyarakat sangatlah penting.

Selain itu terdapat dua dampak negatif migrasi terhadap pembangunan ekonomi di desa yaitu keseimbangan struktural antara kota dan desa yang memburuk. Dimana, pertama dalam sisi penawaran, migrasi internal secara berlebihan akan meningkatkan jumlah pencari kerja di perkotaan yang melebihi tingkat atau batasan perkembangan penduduk. Munculnya para imigran tersebut cenderung meningkatkan penawaran tenaga kerja di perkotaan, sementara persediaan tenaga kerja yang sangat bernilai di pedesaan semakin berkurang. 


\section{Published December 2018}

\section{EKONOMIKAWAN : Jurnal Ilmu Ekonomi dan Studi Pembangunan}

ISSN : 1693-7600 (Print), ISSN : 2598-0157 (Online), http://jurnal.umsu.ac.Id/index.php/ekawan

Kedua, dalam sisi permintaan, penciptaan kesempatan kerja di perkotaan jauh lebih mahal dan lebih sulit jika dibandingkan dengan penciptaan lapangan kerja di pedesaan, sebab jumlah jenis pekerjaan di sektor industri di perkotaan memerlukan berbagai komplementer yang begitu banyak jenis dan jumlahnya.

Dilain pihak, dorongan kenaikan upah di perkotaan dan tuntutan karyawan untuk mendapatkan berbagai tunjangan kesejahteraan, serta tidak tersedianya berbagai teknologi produksi "tepat guna" yang lebih padat tenaga kerja juga membuat para produsen sulit menambah karyawan sebab peningkatan output sektor modern sekarang tidak diharuskan melalui peningkatan jumlah tenaga kerja atau produktivitas tenaga kerja. Begitu juga menurunnya jumlah sumber daya manusia untuk melaksanakan beberapa pekerjaan yang bersifat sosial atau kegiatan gotong royong untuk membangun desa. Bila hal ini berlangsung lama dikuatirkan sifat gotong royong/kerjasama dan kehidupan sosial yang ada di desa saat ini semakin lama semakin hilang.

Migrasi sirkuler dapat berdampak terhadap perekonomian keluarga yaitu terciptanya keseimbangan ekonomi antara kota dan desa yang merupakan suatu unsur penting yang tidak dapat dipisahkan dalam strategi menanggulangi masalah-masalah pengangguran di desa-desa, upaya pengentasan kemiskinan absolut dan perbaikan distribusi pendapatan sehingga mengurangi laju pertumbuhan penduduk, dengan menggalakkan programprogram keluarga berencana dan penyediaan pelayanan kesehatan di daerah-daerah pedesaan dan perluasan industri kecil yang padat karya. Kesempatan kerja disini membutuhkan lebih banyak tenaga kerja bagi setiap unit yang dihasilkan dan setiap unit modal dari produk atau produk-produk lainnya.

Peningkatan ekonomi desa dapat meningkatkan pembangunan ekonomi Indonesia. Untuk peningkatan pembangunan ekonomi Indonesia, tentunya tidak dapat terlepas dari pembangunan ekonomi di desa-desa. Pedesaan merupakan bagian penting dari perencanaan dan pembangunan. Hal ini sejalan dengan kondisi kemiskinannya. Masyarakat pedesaan yang sebagian besar mata pencahariannya adalah petani, sulit sekali untuk keluar dari zona kemiskinan. Ada baiknya ketahanan suatu bangsa dilihat dari kondisi daerah-daerah, yaitu desa, sehingga dapat diketahui faktor-faktor terjadinya migrasi. Peningkatan ekonomi desa inilah akan membuat semakin kuatnya perekonomian dan pembangunan nasional. Dengan adanya migrasi yang terkondisikan dengan baik, maka kemudian akan membuat suatu keseimbangan perekonomian antara desa dan kota.

Kesempatan ekonomi yang setara antara desa dan kota akan menimbulkan suatu kesempatan kerja yang setara antara desa dan kota sehingga kemudian tingkat migrasi bisa ditekan kembali, sehingga keseimbangan perekonomian desa dan kota bisa terus terjaga. Adanya peningkatan ekonomi desa melalui migrasi ini dapat dijadikan solusi bagi pembangunan ekonomi di Indonesia. 
Published December 2018

EKONOMIKAWAN : Jurnal Ilmu Ekonomi dan Studi Pembangunan

ISSN : 1693-7600 (Print), ISSN : 2598-0157 (Online), http://jurnal.umsu.ac.id/index.php/ekawan

\section{SIMPULAN}

Migrasi merupakan proses perpindahan penduduk dari satu tempat ke tempat yang lain yang produk marjinal sosialnya nol ke produk marjinal sosialnya bukan hanya positif, tetapi juga akan dan dapat meningkat sehubungan dengan adanya peningkatan modal dan kemajuan teknologi. Migrasi sirkuler merupakan solusi dari salah satu faktor penting untuk membangun ekonomi desa. Migrasi sirkuler dapat berdampak positif dan negatif. Dampak yang ditimbulkan tidak hanya dalam segi ekonomi, melainkan juga dari segi sandang, pangan, papan, pendidikan, kesehatan, dan infrastuktur desa. Untuk itu, proses migrasi sirkuler perlu adanya pensinergian antara pembangunan di kota dan di desa supaya tidak adanya ketimpangan jumlah penduduk. Dampak dari migrasi sirkuler yaitu penciptaan keseimbangan ekonomi antara kota dan desa, yang merupakan strategi dalam perluasan lapangan kerja yang tidak hanya di kota tetapi juga di desa sehingga secara tidak langsung dapat mengurangi jumlah migrasi. Pembangunan ekonomi Indonesia secara merata akan tercapai, baik di desa maupun di kota.

\section{DAFTAR PUSTAKA}

Biro Pusat Statistik. 2017. Laporan Tahunan Tenaga Kerja, Dinas Tenaga Kerja, Kabupaten Deli Serdang.

Elfindri dan Bachtiar. 2005. Ekonomi Ketenagakerjaan, University Press.

Goldscheider, Calvin. 1985. Populasi, Modernisasi dan Struktur Sosial. Terjemahan oleh Algozali Usman dan Andre Bayo Ala. CV Rajawali, Jakarta.

Hossain, M.Z., 2001. Rural-Urban Migration in Bangladesh: A Micro-Level Study, Research Presentation in The Brazil IUSSP Conference, August 20-24, 2001.

Mantra, I.B. 1978. Population Movement In Wet Rice Communities : a case study of two Dukuh In Yogyakarta Special Regio(Terjemahan). Gajah Mada University Press, Jakarta.

Mulyadi. 2003. Ekonomi Sumber Daya Manusia dalam Perspektif Pembangunan. Raja Grafindo Persada, Jakarta.

Lee, Eevert, 1966. Teori Migrasi. Diterjemahkan oleh Hans Daeng. Pusat Penelitian Kependudukan. Universitas Gajah Mada, Yogyakarta.

Todaro, Michael P. dan Stephen C. Smith. 2004. Pembangunan Ekonomi di Dunia Ketiga. Edisi ke 8. Erlangga, Jakarta. 